\title{
David Hare's The Absence of War: Still Writing "Left-Handedly" in an Age Deprived of Ideology*
}

\author{
ARŞ. GÖR. TUĞBA AĞKAŞ ÖZCAN**
}

\begin{abstract}
British political drama in the 1990s was observed to be concerned not only with the state of the nation but also with the global issues. The repercussions of the fall of the Berlin Wall, the disintegration of the Soviet states, the rise of the United States as the ultimate world power as well as the prevalence of the rightist politics at home were widely handled in the political plays of this period. In this decade, the boundaries between the Right and the Left appeared to be indistinct; therefore, British political drama, which was originally leftist, was assumed to be superannuated. Yet, the established political dramatists together with the new generation of playwrights continued writing politically, though in a different manner, and contributed a lot to the development of political drama. David Hare, one of the leading political playwrights, wrote The Absence of War in 1993 and questioned the very institution of leftist ideology in Britain, Labour Party. However, what Hare critically approached in the play was not leftism itself but the Labour's politics tainted by rightist values. Hence, though criticising the Labour and though writing in an age when ideologies were becoming steadily less effective, Hare preserved his leftist stance. Within this context, this study aims to display how Hare in The Absence of War queries and asks for the reformation of the conservative traces in Labour Party.
\end{abstract}

Keywords: British political drama, right and left, David Hare, The Absence of War, Labour Party

\section{DAVID HARE'İN “SAVAŞIN YOKLUĞUNDA” OYUNU: İDEOLOJIDEN MAHRUM BİR DÖNEMDE HÂLÂ “SOL ELLE” YAZMAK}

Öz

1990'lar İngiliz politik tiyatrosunun, sadece ülke içindeki toplumun içinde bulunduğu durumla değil küresel sorunlarla da ilgilendiği görülmüştür. Berlin Duvarı'nın yıkılmasının, Sovyet devletlerinin dağılmasının, Birleşik Devletler'in dünya devi olarak ortaya çıkmasının ve iç politikada da sağ politikaların egemen olmasının etkileri dönemin politik tiyatro eserlerinde yoğun bir şekilde incelenmiştir. Bu on yıl içerisinde, Sağ ve Sol arasındaki sınırlar belirli belirsiz hale gelmiştir; bu nedenle, aslen sol görüşlü olan politik tiyatronun miadının dolduğu düşünülmüştür. Fakat var olan politik tiyatro yazarları yeni nesil tiyatro yazarlarıyla birlikte, farklı bir tarzda da olsa, politik açılardan yazmaya devam etmişlerdir ve politik tiyatronun gelişimine katkıda bulunmuşlardır. Önde gelen politik tiyatro yazarlarından olan David Hare, 1993 yılında The Absence of War (Savaşın Yokluğunda) eserini yazmış ve sol ideolojiyi Britanya'da temsil eden asıl kurumu, Labour Party'i (İşçi Partisi'ni) sorgulamıştır. Yalnız, Hare'in oyunda eleştirel yaklaştı̆̆ı husus, sol görüşün kendisi değil, sağ

\footnotetext{
* A different version of this study was already produced by the author in her doctorate thesis entitled as "The Evolution of David Hare's Political Drama as Observed in Fanshen, The Secret Rapture and The Absence of War"

${ }^{* *}$ Hacettepe Ün. İngiliz Dili ve Edebiyatı, tuubaagkas@gmail.com, orcid: 0000-0002-4585-0338

Gönderim tarihi: 20.10.2021

Kabul Tarihi: 14.12.2021
} 
değerlerin etkisi altında olan parti politikalarıdır. Bu nedenle, Labour Party'i (İşçi Partisi'ni) eleştirmesine ve ideolojilerin gittikçe daha az etkili bir dönemde yazıyor olmasına ragmen, Hare sol duruşunu muhafaza etmiştir. Bu bağlamda, bu çalışma, Hare'in The Absence of War (Savaşın Yokluğunda) oyununda, Labour Party (İşçi Partisi) içerisindeki muhafazakâr değerleri nasıl sorguladığını ve bunların giderilmesi gerektiğini nasıl savunduğunu göstermektedir.

Anahtar sözcükler: İngiliz politik tiyatrosu, sağ ve sol, David Hare, The Absence of War (Savaşın Yokluğunda), Labour Party (İşçi Partisi)

\section{INTRODUCTION}

B ritish political drama in the 1990s was extensively influenced by not only national politics but also global politics and conflicts. The end of the Cold War resulted in the appearance of the United States as the world power along with the dominance of capitalism. Since socialist prospects were also suspended, the distinction of the Left from the Right began to get obscure both in Britain and around the world. In the 1990s, Conservative governance was prevailing, though without Thatcher, and it was followed by the Labour Party government, who came to power only after reforming its leftist principles. Thus, political dramatists had no other choice but to present the ideological ambiguity prevalent in the decade. This study examines David Hare as a political dramatist with leftist views writing in the "post-ideological" 1990s (Wade, 2007, p. 75) and shows how he reflects the political atmosphere in this decade. For this aim, the present study will first lay bare the political climate in the world as well as in Britain. Thereupon, it will make an introduction to Hare's state-of-the-nation trilogy produced at the turn of the decade. In the trilogy, Hare is concerned with the principal institutions of Britain, namely, church, courts and political parties, respectively in Racing Demon (1990), Murmuring Judges (1991), and The Absence of War (1993). Yet, this study will focus on Hare's criticism of Labour Party in the last piece, The Absence of War, to uncover his persistent trust in leftist ideology although he has a cynical approach to Labour Party politics and although he seeks for "common good" (Hare, 1993a, p. 8) in institutions governed by rightist values.

\section{THE STATE OF THE WORLD AND OF BRITAIN IN THE 1990S}

The principal attribute that characterises the world in the 1990s was the rising of the United States as the major power because the Cold War between the two poles of power had ended with the gradual collapse of the Soviet Union in 1991. European Communism came to an end not only due to the Soviet's disintegration into Russia along with smaller independent countries but also due to the fall of the Berlin Wall in 1989. (Dorney, 2009, p. 200; Sierz, 2012, p. 28-29) As a consequence of such "massive changes in the geo-political system," a New World Order was established (p. 28). In accordance with this new order, United States and its capitalistic politics happened to pervade the international relations in "military/political" terms, as observed in its attempts to establish authority through military operations in Persian Gulf, Iraq, and the Middle East, which it conducted allegedly for the purpose of a "stable" world order (Y1lmaz, 2008, p. 45). Moreover, with the collapse of the Soviet Union, communism as a system of governance started to retreat from international arena since it "lost its missionary appeal" (Van Tassell, 1991, p. 257). As 
the efficacy of leftist ideology relatively mitigated, the tension of the binary opposition between leftist and rightist ideologies cooled to a certain extent in the 1990s.

As for Britain, after eleven years of governance, Margaret Thatcher was replaced in 1990 by John Major both as the head of the Conservative Party and as the Prime Minister of the United Kingdom. When Major came to power, what the Conservatives and the public wondered was whether Major's policies would be different from or similar to those of Thatcher's in terms of ideology and the way of handling the economy. The Major government itself "was always torn between stressing its ideological links with Thatcherism and attempting to emphasise its distinctiveness" (Shellard, 1999, p. 189). With Major's first election, the 1992 General Election, it was thought that the Thatcherite politics that haunted the country for more than a decade would come to an end. However, Major kept some Thatcherite policies, especially certain economic measures that could win the electorate's favour. Nevertheless, at the same time, he disposed the poll tax in 1991 and changed the government's policy related to Europe, which "established the necessary distance between himself and his predecessor" (Heffernan and Marqusee, 1992, p. 302). Hence, in spite of the Labour Party leader Neil Kinnock's election campaign with a centrist approach rather than a strictly socialist one, the Conservatives were victorious in 1992, "w[inning] more votes than any other party in history and the biggest percentage lead since 1945" (Dorney, 2009, p. 199). However, in the 1997 General Election, Tony Blair, who replaced Kinnock, became the Prime Minister as a result of Labour Party's victory. Labour Party under Blair was branded as New Labour, whose politics was in the middle ground between the Right and the Left. The Labour government under Blair endorsed "Third Way economic policies" by "marrying free-market economics and social liberalism" (Urban, 2008, p. 40). Hence, even with a party from the Left in the government, the dominance of the rightist politics continued in the social life and institutions of Britain.

\section{THE STATE OF THE BRITISH POLITICAL DRAMA IN THE 1990S}

Given that the New World Order was in tune with capitalist essentials after the fall of the Berlin Wall as well as the Soviet disintegration and that the order in Britain was heavily under the influence of Conservative politics even when a Labour government was in power, it is not a coincidence that political drama, with its leftist tendencies, was widely considered to be dead in the 1990s. Nonetheless, in this decade, apart from the politically conscious works of a new generation of playwrights, the writings of the established political dramatists were "re-energized" so as "to create fresh sociopolitical critiques" (Kritzer, 2008, p. 25-26). Thus, it can be stated that political drama maintained its existence in the 1990s with the contribution both of the established dramatists and of the newly-arising young playwrights.

To begin with, the established political dramatists like David Hare, David Edgar, Caryl Churchill, Howard Brenton continued writing - still from a leftist point of view - socially and politically conscious plays which were held in high esteem both by the public and by mainstream theatres of Britain. Despite the fact that some new generation of playwrights and critics like Aleks Sierz assume that "forms of 1980s political drama such as the state-of-the-nation play" became out- 
dated in the 1990s (as cited in D'Monté and Saunders, 2008, p. 20), the political dramatists brought out "successful work based around these supposedly redundant forms throughout the 1990s and beyond into the millennial decade" (D'Monté and Saunders, 2008, p. 20). However, it is of vital importance to point out what was disparate in these established political playwrights' tone of voice in the 1990s as opposed to the one they adopted in the previous decades. The 1990s were characterised by the distrust of ideologies, which is a fact not only among the public but also among the political dramatists. Les Wade (2007) defines this new world as "a post-ideological" one in which "honouring the inviolability of the other, with no clear path or directive, comprise[d] the core of ethical decision-making" (p. 75). Hence, according to Amelia Kritzer (2008), the approach mostly embraced by the political dramatists was humanism rather than any political -ism (p. 219). Hard though it is to expect political dramatists to have put aside all their ideological dreams, it can be asserted that they reduced emphasis in the 1990s on their socialist claims as an ideal system of governance.

\section{DAVID HARE'S CYNICAL ATTITUDE TO LABOUR PARTY IN THE ABSENCE OF WAR}

David Hare's state-of-the-nation trilogy at the turn of the decade, when the boundary between the ideologies of left and right blurred, inspects the major institutions of Britain, those of religion, law and politics from a leftist perspective, respectively in Racing Demon (1990), Murmuring Judges (1991), and The Absence of War (1993). Engagement with institutions is not a novelty in Hare's drama because, in his career, he has always been "a passionate and unrelenting critic of the establishment and of what we may call 'the official culture'" (Boon, 2003, p. 1). Since it is Hare's aim as a political dramatist to lay bare the social and political matters of his time, the public institutions are issues he inevitably takes into consideration. He has a satirical approach to educational institutions in Slag (1970); he reprehends the shortcomings and mistakes of the Labour movement in The Great Exhibition (1972); he makes a critical analysis of the capitalist ideology penetrating into various institutions and private lives in Knuckle (1974); he presents the rock'n'roll movement in an unfavourable way and undermines an established institution, Cambridge University, in Teeth ' $n$ ' Smiles (1975); he describes how to apply socialism properly in different institutions like law, police force, health, and education as seen in Fanshen (1975); he criticises British bureaucracy in Plenty (1978); and he, together with Howard Brenton, denounces the media industry in Pravda (1985).

When dealing with the establishment in his plays, Hare portrays individuals who are constantly in contact with the institutions. In addition, what Hare has in his mind while playwriting is to portray the society as it is, as it is in relation with private and public embodiments. Hare (2005) believes that "if at least the ambition to be urgently contemporary goes out of our theatre, then we will have lost the thing which most distinguishes it and makes it valuable" (p. 105). As a result of this ambition, through his trilogy, Hare intends to provide for his audience "some of the problems facing people working in the law, the church and the Labour Party" so that they can find "any resonance with the experience of their own lives" (p. 141). What Hare presents on stage is not only pure representation but a critical analysis because theatre is the 
"proper place" where the playwright is able "to tackle the major social and political issues of contemporary society" (Boon, 2007, p. 31). In this respect, Hare's reflection on the contemporary politics in the trilogy is completely in line with the way he has handled politics and society since the beginning of his career.

The trilogy, nevertheless, has a distinguished place among Hare's plays and it is different from his earlier plays that deal with social and political issues. The principally distinctive attribute of the trilogy is its approach to its material. The trilogy plays were written at times when there was no ideology wholeheartedly embraced other than the Conservative and when there seemed no escape from the Conservative rule. At those times, furthermore, there was no way left for the playwrights to bring a solution to "the corrosive effects of a Conservative hegemony (and the failings of British institutions)" apart from espousing the Conservative ideology (Wade, 2007, p. 65). Under the conditions that prevented any war against the "naturalised" institutions or against the Conservative discourse that "masquerade[d] as common sense," Hare, as a political dramatist, felt obliged to advocate the institutions on condition that they were reformed (Pattie, 1999, p. 365366). This is, for Hare (1993a), the "irony of Thatcherism" in that "[Thatcher] made conservatives of us all. We all found ourselves defending institutions which previously we would have had no time for, because those institutions were better than barbarism" (p. 228). Wherefore, Hare preferred to explore "the common good" for the people in his trilogy rather than to uphold a certain religious or political ideology (p. 8). Since there seemed no escape from the institutions, he sought this common good within these institutions by renewing and reforming them (p. 88).

Les Wade (2007) argues that, as Hare does not underline a definite ideology in his trilogy, the plays "demonstrate a political agnosticism" (p. 65). On the one hand, this is true because there is a protagonist in each play that represents goodness, decency and morality without depending on a spiritual, legal or political foundation. Lionel in Racing Demon works hard to help the poor and to raise consciousness about their living conditions with no or little reference to Christ or to what the Church of England requires him to do. Irina in Murmuring Judges strives to establish justice challenging the prejudiced judges and the legal constraints. George in The Absence of War represents decency as a politician in the midst of the cruel conditions of British politics and, even when he loses, he searches for new ways of serving the people. On the other hand, to seek and to provide the common good for the public who was, to a great degree, under the influence of the Conservative politics in the 1990s is not at odds with leftist ideology. Therefore, it can be stated that Hare wrote the plays of the trilogy "left-handed"ly as the title of one of his prose works, Writing Left-Handed (1991), indicates and as he himself implies in his non-fiction work Asking Around.

Another distinctive feature of the trilogy that sets it apart from Hare's previous engagements with social and political institutions is its employing the form of verbatim theatre and being one of the precedents of this form. Verbatim theatre, as a theatrical practice, appeared and was widely used in the 2000s; but David Hare's trilogy happened to be one of the initiative examples. In verbatim theatre, the playwrights, while constructing the plays, put into use the researches, the inquiries, and the interviews that they themselves conduct (Haydon, 2013, p. 42). Likewise, prior to 
the writing process of his trilogy, Hare collected information making inquiries at the Church of England, at the Inns of Court, at prisons and with policemen, and lastly in the Conservative and Labour parties. Then he put his research together in Asking Around (1993) as a source book for the trilogy. What distinguishes Hare's trilogy plays from the verbatim plays of the 2000s is the fact that Hare fictionalised in his trilogy the facts he found out rather than producing an unadulterated representation. Moreover, the fieldwork Hare conducted not only made his plays initial examples of verbatim theatre but also "attempt[ed] to counter the influence of mass media, especially television, in the selection and viewpoint of material" since they depended upon the playwright's own "documentary-type reports on controversial events" (Kritzer, 2008, p. 24). That is why Billington (1993) calls the last piece of the trilogy, The Absence of War, journalistic. However, he also points out that "[the play] is both too journalistic and not journalistic enough" (n. pag.). Since the play is based on Hare's research and records, it may be regarded journalistic; on the other hand, since it is a dramatic work of art, it is relieved from the constraints of journalism and the playwright can treat his material however he likes, by adding fact or fiction to it. In the play, for instance, Hare deals with the factual matters, which he also illustrates in the non-fictional source work Asking Around; but what he does in the plays as distinctly is to fictionalise and to individualise the characters as well as to employ his dramaturgy.

In The Absence of War, David Hare, as a political dramatist with leftist ideology, is observed to be critical more of Labour Party, its members and policies than of Conservative Party. The Absence of War is regarded to be one of the works which "directly confront the unpopularity of the left" and which oppose the claim that the political writers already "decamped to the Conservatives" (Ansorge, 1997, p. 48). In the play, Hare sincerely discloses the shortcomings and the defects of the Labour especially in terms of pursuing leftist principles and mastery of economy. Meanwhile, he retains his leftist stance and continues to favour Labour Party as he implies in the play and explicitly states in Asking Around (1993a, p. 242). This study will cast light upon how critical of the Labour Hare is and to what extent does he remain a leftist and, for this purpose, it will scrutinise Hare's treatment, in The Absence of War, of the Labour Party preparations for the 1992 General Election by referring, when necessary, to the source book, Asking Around.

One of the initial problems with Labour Party, as portrayed in The Absence of War, is the fact that the members of the party seem to have created a closed society for themselves. These members who have a shared past of leftist 'struggle and revolt' are so loyal to each other that they become cynical towards any interference or criticism from the outside. However, such an obstinate adherence to the thought that they can trust only each other makes them distant from the modern world and deprived of its opportunities. For instance, Labour Party needs an agency to conduct campaign for the elections but the members insist that "We have a campaign. We've even fixed slogans" (Hare, 1993b, p. 14, 1.4). The members obstinately believe that an advertising agency should help them only for the print and the posters not for the slogans or the political statements. They distrust the "[p]rofessionals" of the post-Thatcherite Britain (p. 17, 1.4) since, for them, these professionals have little experience of struggling, which is crucial in Labour Party. Such a portrayal of the Labour members in the play originates from the fact revealed in Asking Around. As 
far as Hare observed in Conservative and Labour headquarters, while the professionals of the Post-Thatcherite Britain under the Conservative rule had self-assurance which was untainted by any loss or failure, the Labour Party members had a feeling of weariness after successive Conservative victories in the elections and "thirteen years' powerless opposition" (1993a, p. 213). As a result, Labour Party adopted a kind of stoicism and isolated itself from any newcomer who was fresh, who did not experience defeat, and who learnt the Labour principles only recently.

On the other hand, it is hard for Labour Party, as far as dwelled in The Absence of War, to survive the elections without getting assistance from outside of the party or to "fight an election without Professional help" when the Conservatives make use of all the facilities of the modern world (Hare, 1993b, p. 6, 1.2). In isolation, Labour Party ends up distant from the public and ignorant of the main reasons that lie behind its past defeats in the elections and of the public opinion about their present politics. It has its own polls and surveys but these are not very helpful in providing a truthful analysis of the public opinion. Besides, they only cause Labour Party to change their policies "so often that no one quite knows where [the] Party stands" (p. 67, 2.3). Furthermore, the Labour Party members are not aware of the fact that their timorous slogans which are constructed for fear of aggravating the Conservative policies make them shift towards the right. In fact, the character from the advertising agency, Lindsay warns them about the facts she extracts from the opinion polls but the members, particularly Oliver, Andrew and Bryden turn a deaf ear to what she says. According to the surveys, for instance, "[s]eventy per cent agree with this statement: 'The Labour Party no longer stands for anything distinctive'" (p. 28, 1.6) because their policies are no longer distinguishable from those of Conservative Party.

To illustrate Labour Party's gradual shift towards the right discarding its basic principles, it is implied in The Absence of War that their agenda for the election is prepared in conformity with the discourse constructed by the Conservative governments. It is the Labour's lack of confidence that makes them "fight the election on grounds dictated by their enemies" (Wu, 1995, p. 114). For instance, the fictional Labour leader, George, who is the counterpart of Neil Kinnock, is made to speak in a 'conservative' manner and even his speeches are worked out so meticulously that certain words favoured by the Conservatives are used such as "fairness," leaving aside one of the key words of socialism, "equality" (Hare, 1993b, p. 43, 1.8). However, to avoid asserting their own ideas not only makes Labour Party inefficient in the eyes of the electorate but also distances them from their roots and ideals. Although conforming to the Conservative discourse means playing their cards safe, this state of safety, "no big punches, just slugging it out," makes both George and his party "very boring" (p. 47, 1.8). Moreover, by submitting to the Conservative ideology, Labour Party relinquishes one of the fundamentals that underlie the socialist doctrine, which is "to disagree," as Vera reveals in the play (p. 50, 1.9). Vera is the fictional character who represents the generation of the late 1960s, who disagreed with the conventions of their time and who fought for their own ideals. Although Vera is called to Labour Party campaign headquarters "[a]s a symbol of roots [a]nd continuity," she is not allowed to speak (p. 51, 1.10). Since Labour Party has already distanced itself from its roots, it is not a surprise when the ones who have invited Vera to leave her alone on stage immediately after the programme for the campaign starts (p. 56; 1.10). However, as 
Hare suggests in the play, Labour Party needs to consult such figures from its history in order to prove that it is still loyal to its roots.

Apart from its inadequate attempts to construct a kind of connection with the leftist history, another problem with Labour Party, as reflected upon in The Absence of War, is its broadly assumed impotence in economy in an age permeated with capitalistic principles. According to George, the Labour Party leader in the play, the Conservatives give prominence to and glorify "[m]oney" and it is "a simple master" which can effortlessly bring varied people together and appeal to the electorate (Hare, 1993b, p. 18, 1.4). The Conservatives work alongside and in harmony with the outside world with which they have the same concerns, that is money, as underlined in the play. In real world as well, particularly in those Conservative years under Thatcher's rule, British politics was predominated by such money-centred terms as the free-market economy, monetarism and privatisation. Together with Thatcher's rule, "[t]he language of politics changed" and it became impossible "to cover politics properly if you weren't economically literate" (Gardam, 1993, p. 209). Accordingly, throughout a decade, the political debates mainly focused on the economy which most of the people could not comprehend adequately (p. 210). During these debates, it was always the Conservatives who were pointed out as the ones capable of handling the economy. After Thatcher, the John Major government, too, were intent to produce a softer approach to conservatism but, as far as the experts pinpointed, it did not appeal to the electorate to be both "Capable" in the economy and "Caring" towards the people at the same time (Hare, 1993a, p. 202). Hence, the Conservatives under Major followed Thatcher and accepted the superiority of mastering money over adopting a softer ideology.

The Labour Party, on the other hand, as emphasised in Asking Around, set out with the promise of providing both "justice and efficiency," which are, in other words, kindness/fairness and economic capability (Hare, 1993a, p. 202). However, their policies did not appeal to the electorate both because it was widely accepted that it was hard to be both altruistic in the relations with the public and competent in terms of economy, and also because Labour Party was already accepted inept in affairs related to the economy. This fact is also underlined in the play by George, who states that the Labour Party members uphold the "justice" superior; however, for him, it is a problematic term since "no two people agree what it is" (1993b, p. 18, 1.4). He further elaborates on his claims as such: "Justice has no organizations. It has no schools. It did have once. They were called unions. But the communities that produced them have gone. The industries have gone. So now justice recruits from the great deracinated masses. The people from nowhere. Who have nothing in common? Except what they say they believe in" (p. 18, 1.4). 'Justice,' the term that David Hare fondly employs in many of his plays, appears in The Absence of War as an ideal which is sought by Labour Party but which has no power to bring together various groups of people each of whom have different perceptions of justice. Though the Labour Party members adopt justice as a master, justice is not capable of attracting the electorate on its own. Hence, while the Conservatives' master, money, brings victory, the Labour's master, justice, though dignified, brings loss. 
The Conservatives' 'master,' as it is disclosed in Asking Around, attracts people so efficiently and the Conservatives' mastery of the economy is accepted so readily by the public that every political act of the Conservatives is assumed as a contribution to the economy. When the Conservative Party leader John Major goes to a "microchip factory on a featureless industrial estate in mid-Glamorgan" as a part of his election programme, a journalist questions Major's going around in a factory to make a speech on the election and talks with one of Major's officers:

Minder: ... This is a place where modern technology is being developed.

Journalist: What for?

Minder: Helping the economy.

Journalist: In what way?

Minder: I don't know, but I'm sure it's helping the economy. (Hare, 1993a, p. 197)

Therefore, the fear of disturbing the Conservative discourse, which is steadily established as observed above, makes the Labour conceal their own politics and plans related to the economy. For instance, there is an important matter in the economy that Labour Party intends to find a solution for in the play, The Absence of War, which is mortgage tax relief. The people in the Labour see that it is "the propertied class" that benefit from this tax relief, which is "unearned" and "unequitable" (1993b, p. 45, 1.8). The Labour, as a party aching for "common fairness," wants to abrogate it but it is for certain that this change will disturb the class with property (p. 67, 2.3). Thus, the people in the Labour are determined to keep their plan about this change a secret as if they were not defenders of common property in opposition to private property.

Since the Conservatives are supposedly good at managing money, the Labour both in the play and in real world surrender the economy to them without any hesitation. Not only the widely-assumed Conservative superiority in the economy but also the Labour's previous failures in the economy make the latter refrain from matters related to the economy. Owing to the fact that the Labour governments could not be triumphant in resolving the economic problems in the 1970s, the public in the 1980s and in the early 1990s tended to distrust Labour Party's politics in this realm. Moreover, as exposed in Asking Around, before the election, Maurice Saatchi, an Iraqi-British businessman, put "TAX BOMBSHELL' posters which convinced voters they would each be $£ 1.000$ worse off under Labour" (Hare, 1993a, p. 163). Since Labour Party could not respond to this challenge properly, it was widely accepted that "Labour had lost before they began" (p. 163). As for in the play, The Absence of War, the assumption that Labour Party will fail in the economy is accepted even by the party members themselves: "We have been through this many times. Finally, the economy is always going to be a Tory issue. It's theirs. They own it" says Oliver, a Labour Party member in the play (1993b, p. 44,1.8). Furthermore, the playwright himself observes when he is among the party members that "Labour strategists regard tax and the economy as issues on which Labour simply cannot win" (1993a, p. 183). Even so, according to the statistics, "Labour governments since the war have been at least as economically successful as Tory ones, if not more so" (p. 212). In fact, the Labour, rather than being obsessed with their own failures, could focus on the inefficacy of the Conservatives in the economy such as "unemployment, worst recession since the war, the poll tax fiasco" as the Labour leader Neil Kinnock's secretary Julie Hall admits (p. 227). Yet, Labour Party in the play impulsively sees the economy as "a Tory issue," so its members 
make the economy one of the taboo subjects that their leader George is to refrain from in his speeches. For Oliver, "George can speak all he likes on the caring issues. Health. Education. He plays to his pluses, that's fine. What he mustn't do is in any way remind people that when he's elected he's going to be in charge of their money. Because that's where people don't trust him at all" (1993b, p. 44, 1.8).

Accordingly, it is not a coincidence in the play that even the possibility of a Labour government according to a new opinion poll causes the pound to fall. It also leads to chaos and confusion both throughout Britain in general and particularly in Labour Party's offices. The Labour Party members along with their leader have already decided that "We must never seem to talk the pound down" and that they should "stop the pound falling. At all costs" since it would be "unpatriotic" (Hare, 1993b, p. 27, 1.6). However, it is not Labour Party's job to deal with an economic problem since the Conservatives are in the government at present. Thus, what Labour Party does is nothing other than "help[ing] the Tories" (p. 27, 1.6). As Lindsay asserts, almost all of the deeds of Labour Party "seem to be backing the government" so much that "the public ends up thinking [they]'re weak" (p. 28, 1.6). Although as patriotic members of the society the people in the Labour claim that they are worried about the economic concerns of the public, they are, in fact, fearful of any adverse effect this recent poll and the fall in the pound may have on the vote rates of their party in the election. As the factual statistics in Asking Around tell, "[o]nce it is understood that the Labour may win, there will undoubtedly be a shift back to the Conservatives" as known among the people (1993a, p. 213). Therefore, even though the surveys indicate Labour Party started its campaign for the 1992 General Election ahead of Conservative Party, it ended in unsuccess. As a direct result of the distrust in Labour Party in the field of the economy, "the number of people [increased] believing that a Labour government w[ould] mean higher taxes every day" (p. 217). This prejudice was also advocated by the newspapers which worried about what would become of Britain when Neil Kinnock came to power. What particularly astonished the Labour only one day before the election was the fact that "[t]he Sun ha[d] nine pages on what a nightmare it would be if Neil got in, similarly the Express and the Mail" (p. 222).

Other than economy, there are some other issues which the Labour Party members in the play believe they should talk about within the boundaries that the Conservative discourse allows them. In the ninth scene of Act II, the readers/audience witness the outburst of George when he reveals, in a state of delirium, a number of issues he is forbidden to talk about. One of these issues is the Northern Ireland problem: George is instructed by his team to assume that Northern Ireland is "above politics" and it is a matter "too important to be spoken of" so he had better not talk about it "publicly" (Hare, 1993b, p. 98, 2.9). Another issue that George cannot make a political comment about is British history; he is not allowed by his party to state that "Britain happens to be trapped in historical decline" though he believes "it's true" (p. 98, 2.9). British "[d]efence" is another forbidden subject matter to talk on although it is required to defend that "nuclear weapons" are to be abandoned, which George would do if he was allowed to (p. 98-99, 2.9). George is not permitted to criticise "the royal bloody family" and the "hereditary peerages" either (p. 99, 2.9). It is a disillusionment for George not to be able to critically evaluate the state of Britain as he observes it 
is in: "We live in a country which is spavined with ancestorship. This country will never, can never prosper until it escapes from its past. (He turns and addresses them all.) Why can't I say that? You tell me. What is this? Is this my fault? Or is it the public's? (He turns back away from them.) Why can't I speak of what I believe?" (p. 99, 2.9). These are the last cries of a political leader and his upcoming failure.

Totally immersed in Conservative discourse, Labour Party lost the elections of 1992 as a historical account and as is manifest in the play. There were no wars but elections in the 1990s' Britain for the British politicians to fight for. That is why, the Labour Party members in the play call the notebook in which they noted down, "mapped out, charted and cross-indexed" all their arrangements as "[t]he war book" (Hare, 1993b, p. 42,1.8). According to the Labour members, an election is not "debating" but it is "waging war" (p. 46, 1.8), though, as a result of certain ineffectual strategies, they lost this war. In fact, fighting to win the election really kept the people in the Labour busy and allowed them to feel worthy of esteem. For John Louis Digaetani (2008), the fact that in order to feel worthy of esteem, the politicians work hard instead of fighting in a war and consider their busy lives a substitute for wars is a kind of "transference" (p. 134). When there is no war, as asserted in the play, there are elections to strive for during which especially the opposition party members feel they "exist" at least for a certain period of time (Hare, 1993b, p. 49, 1.8). When there is no election, one party rules the country with their own policies while the opposition party can "do precisely nothing" (p. 49,1.8). That is why The Absence of War deals with what particularly the opposition party does in the absence of war, in preparation for the general election, the only time they are allowed to give voice to their policies so that they can attain a sense of personal value and a feeling of existence.

Although the Labour lost the war, neither the play nor the protagonist allows any despair for the future because, as George and many people in the Labour believe, "[t]he Party is not [their] whole life. But it's all [they] have. It's the only practical instrument that exists in this country for changing people's lives for the good" (Hare, 1993b, p. 104; 2.11). George believes that he did what he could as a leader and he will continue to be a follower and a servant of the party since there is no other "instrument" that is able to realise his dreams. George's feelings about his party illustrate, in a way, David Hare's thoughts about political drama and Labour Party. Just as George and many people in the Labour Party, Hare, as a political dramatist, "ha[s] been saturated, soused, drowned in failure. Failure's [become their] element" because not only the party but also "[t]heatre has changed as little as society" (Hare, 2005, p. 142). However, like George, Hare does not give way to despair since he, along with the other people in the Labour and political dramatists, are "braced by the beauty of what [they]'re attempting, in art as much as in politics. [They] are sustained by the thing itself, its superb difficulty" (p. 142-143). Even though George is criticised, to some extent, for not bringing victory to the party, he is not condemned but even praised for his contributions to the party. Likewise, although Hare does not exalt what he did as a political dramatist, he does not regret, either, how he struggled. What George and Hare did for their political goals can be summarised in Hare's words: "even if it has been a lifetime of failure, it has not been a lifetime of waste" (p. 143). 


\section{CONCLUSION}

All in all, The Absence of War, a piece of Hare's state of the nation trilogy, was a significant political play in the 1990s concerned with a British political party when a great number of political plays appeared to be focusing on global issues. The fact that Hare dramatised his first-hand research in the play and published his research in a separate background source Asking Around authorised him to offer an alternative kind of journalism. Thematically, The Absence of War is a significant representation of the core idea that dominated the 1990s, which was the collapsing distinction between the Right and the Left, as well as of the phenomena of the rising of capitalism and the retreating of communism. What Hare is concerned with in The Absence of War is more than the political institutions; it is the afflictive fact that the Left retreated when people needed it most. Even the leftist politicians lost their belief in their own ideology and came to speak within the limitations of the rightist discourse, which Hare critically treats in the play. Political and ideological agnosticism that permeates the play is not what Hare endorses but what the conditions of the age bring about. Hare, in a decade when the binaries between the ideologies are obscured, writes "left-handed"ly in The Absence of War. Taking into account Hare's leftist perspective, which he honestly displays in the play, it is not a coincidence that The Absence of War is a key work of Hare's, which establishes him as a central figure of British political drama in the 1990s, a decade when it was widely posited that political drama was dead and that the established political dramatists were writing on a centrist strand.

\section{BIBLIOGRAPHY}

Ansorge, Peter (1997). From Liverpool to Los Angeles: On Writing for Theatre, Film and Television. London: Faber and Faber.

Billington, Michael (1993, Oct. 4). Labour's Hare Shirt. The Guardian. The Guardian and Observer Digital Archive. www.theguardian.com. (access 23.10.2013).

Boon, Richard (2003). About Hare: The Playwright and the Work. London; New York: Faber and Faber.

Boon, Richard (2007). Keeping Turning Up: Hare's Early Career. In R. Boon (Ed.), The Cambridge Companion to David Hare. (pp. 31-48). Cambridge; New York: Cambridge UP.

D'Monté, Rebecca and Graham Saunders (Eds.). (2008). Cool Britannia? British Political Drama in the 1990s. New York: Palgrave Macmillan.

Digaetani, John Louis (2008). Stages of Struggle: Modern Playwrights and Their Psychological Inspirations. Jefferson: McFarland.

Dorney, Kate (2009). The Changing Language of Modern English Drama 1945-2005. London: Palgrave.

Gardam, Tim (1993). Interview by David Hare. In D. Hare, Asking Around. (pp. 208-212). London: Faber and Faber.

Hare, David (1993a). Asking Around: Background to the David Hare Trilogy. London: Faber and Faber. Hare, David (1993b). The Absence of War. London: Faber and Faber.

Hare, David (2005). Obedience, Struggle \& Revolt: Lectures on Theatre. London: Faber and Faber. 
Haydon, Andrew (2013). Theatre in the 2000s. In D. Rebellato (Ed), Modern British Playwriting: 2000-2009: Voices, Documents, New Interpretations. London: Bloomsbury.

Heffernan, Richard and Mike Marqusee (1992). Defeat from the Jaws of Victory: Inside Kinnock's Labour Party. London: Verso.

Kritzer, Amelia Howe (2008). Political Theatre in Post-Thatcher Britain: New Writing 1995- 2005. New York: Palgrave Macmillan.

Pattie, David (1999). The Common Good: The Hare Trilogy. Modern Drama, 42(3), 363-374.

Shellard, Dominic (1999). British Theatre since the War. New Haven: Yale UP.

Sierz, Aleks (2012). Modern British Playwriting: The 1990s: Voices, Documents, New Interpretations. London: Methuen.

Urban, Ken (2008). Cruel Britannia. In R. D’Monté and G. Saunders (Eds.), Cool Britannia? British Political Drama in the 1990s. (pp. 38-55). New York: Palgrave Macmillan.

Van Tassell, G. Lane (1991). The New World Order and the Legacy of the Post-Cold War Era in Latin America. Journal of Third World Studies, 8(1), 254-266.

Wade, Les (2007). Hare's Trilogy at the National: Private Moralities and the Common Good. In R.

Boon (Ed.), The Cambridge Companion to David Hare. (pp. 64-78). Cambridge; New York: Cambridge UP.

Wu, Duncan (1995). Six Contemporary Dramatists: Bennett, Potter, Gray, Brenton, Hare, Ayckbourn. London: St. Martin's.

Y1lmaz, Muzaffer Ercan (2008). "The New World Order": An Outline of the Post-Cold War Era. Alternatives: Turkish Journal of International Relations, 7(4), 44-58. 


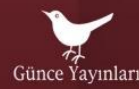

Prof. Dr. Önder Göçgün

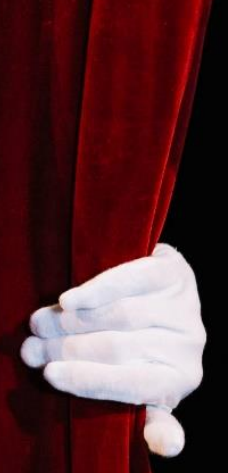

TIYYATRO DENEN HAYAT

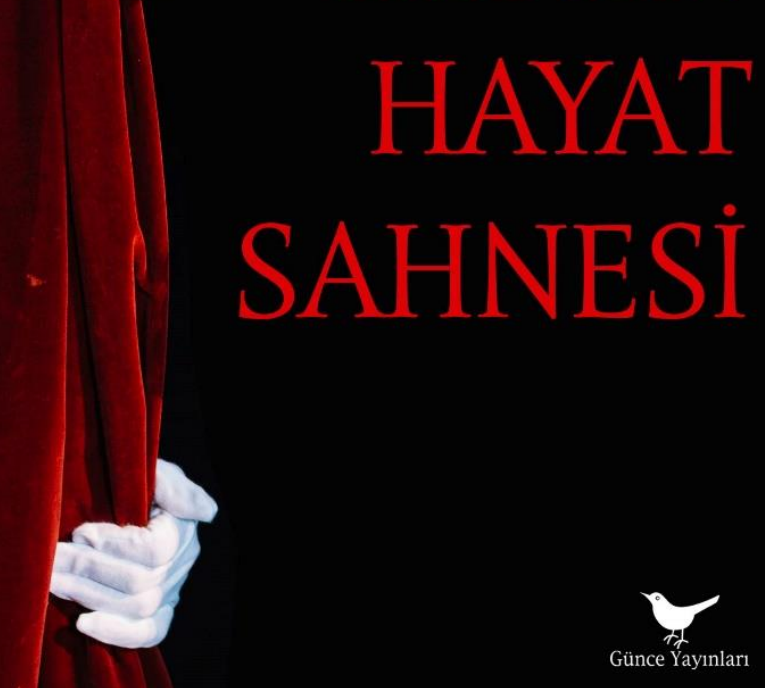

MUIIARREM DAYANC OKTAY YIVLI MACI'I BALIK MAIIMU'I BABACAN SLVIM SLERMEI
YASFMIN MUMCU BLDI் KOÇАKOĞLU NILÜLLLR ILLHAN MAKSUT YIĞITBAS SLL $\triangle M I I L \Lambda N$

\section{EDEBIYATINDA

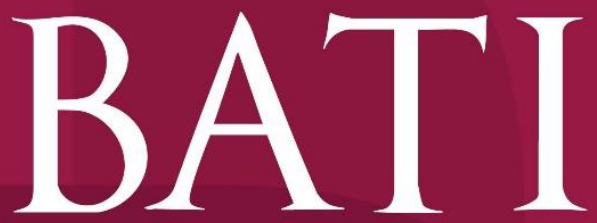 \\ EDEBIYATINDA
AKIMLAR \\ $\underset{\substack{\text { EDEBIYATINDA } \\ \text { AKIMLAR }}}{\mathrm{B} A T \mathrm{~T}}$}

editör

OKTAY YIVLI

HATICE FIRAT

YASEMIN MUMCU

OKTAY YIVLI

OĞUZHAN KARABURGU

BERNA AKYÜZ SIZGEN

NILÜFER ILHAN
ÜMMÜHAN TOPÇU

SEFA YÜCE

HANIFI ASLAN

METIN AKYÜZ

MEHMET SÜMER
YAKUP ÖZTÜRK
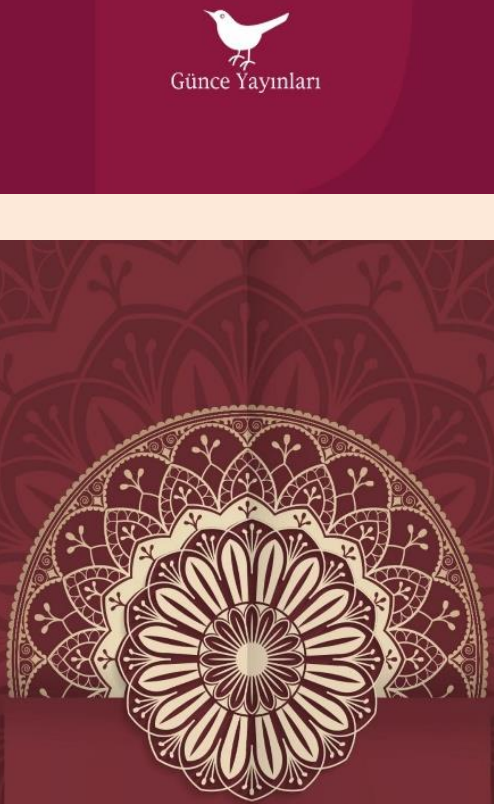

PROF. DR. ÖNDER GÖÇGÜN

$$
\begin{gathered}
\text { Türk } \\
\text { Tasavvuf } \\
\text { Siini }
\end{gathered}
$$

AÇIKLAMALI VE YORUMLU ÖRNEKLERLE 